\title{
Isolated testicular relapse in boys with acute lymphoblastic leukaemia: treatment and outcome
}

\author{
$\mathrm{K}$ TIEDEMANN, J M CHESSELLS, R M SANDLAND
}

\begin{abstract}
In 22 boys among a group of 169 with acute lymphoblastic leukaemia the first relapse occurred in the testis. In 14 of these late isolated testicular relapse was detected on routine biopsy or became apparent after treatment was electively stopped. Eleven of these boys were treated with reinduction, irradiation of 2400 rads to both testicles, intrathecal methotrexate, and two years of chemotherapy; 10 remained well and were in second complete remission from two and a half to five and a half years later.

It is concluded that boys with late isolated testicular relapse fare better than those with late marrow relapse and may have a chance of long-term disease-free survival.
\end{abstract}

\section{Introduction}

In the past few years it has become apparent that, in some centres at least, boys with acute lymphoblastic leukaemia fare worse than girls. ${ }^{12}$ This difference in prognosis is in part accounted for by testicular relapse, which usually becomes apparent within the first year after treatment is stopped. ${ }^{3-5} \mathrm{We}$ report here our experience in managing isolated testicular recurrence in a group of boys with acute lymphoblastic leukaemia treated during a seven-year period; our uniform approach to management seems to have produced more encouraging results than have hitherto been reported.

\section{Patients and methods}

From January 1972 to December 1978, 296 children aged under 16 years were referred to the Hospital for Sick Children for treatment of acute lymphoblastic leukaemia; 169 were boys. The patients were treated with protocols designed or being piloted for the Medical Research Council Working Party on Childhood Leukaemia (UKALL II, III, IV, and V), the details of which have been reported elsewhere. ${ }^{16-8}$

All patients received induction treatment with prednisolone and vincristine and consolidation with a third agent, colaspase. Some received additional drugs-namely, cytarabine, cyclophosphamide, vincristine, and prednisolone (COAP), plus adriamycin and colaspase. All patients received prophylaxis to the central nervous system with cranial irradiation and a course of intrathecal methotrexate or spinal irradiation or both. Continuing (maintenance) chemotherapy comprised mercaptopurine and methotrexate with prednisolone and vincristine; some children also received cytarabine or cyclophosphamide or both. Most children who remained in first complete remission at two years were randomised to receive two or three years' chemotherapy. Before treatment was stopped the bone marrow and cerebrospinal fluid were examined in all patients, and, from mid-1977 onwards, all boys underwent bilateral wedge biopsy of both testicles

Department of Haematology and Oncology, Hospital for Sick Children and Institute of Child Health, Great Ormond Street, London WC1N 3JH

K TIEDEMANN, MB, FRACP, leukaemia research fellow

J M CHESSELLS, MD, FRCP, consultant clinical haematologist

St Bartholomew's Hospital, London EC1A 7BE

R M SANDLAND, FRCS, FRCR, consultant radiotherapist before randomisation to stop or continue treatment. Patients randomised to receive a third year of treatment did not undergo repeat biopsy at the end of the third year.

When routine biopsies were introduced in mid-1977 all boys who had stopped treatment in the previous two years were recalled for 0 biopsy. In those who presented with clinical infiltration the diagnosis के was confirmed by biopsy and bone marrow and cerebrospinal fluid $\vec{\circ}$ were examined, but more extensive staging investigations such as lymphangiography, abdominal ultrasonography, or laparotomy were not performed.

\section{MANAGEMENT OF TESTICULAR RELAPSE}

Two boys who presented with isolated testicular relapse before 1977 were treated with bilateral testicular irradiation and a short $\mathrm{fN}$ course of vincristine and prednisolone. From 1977 onwards a standard $\vec{\partial}$ treatment policy was adopted for boys with testicular relapse whether $\overrightarrow{\vec{a}}$ associated with overt infiltration or diagnosed at biopsy. All patients received systemic reinduction and consolidation with prednisolone $\frac{\mathrm{O}}{\partial}$ and vincristine followed by COAP, adriamycin, and colaspase, and all $A$ received a course of five intrathecal methotrexate injections. Local ${ }_{D}$ treatment comprised 2400 rads ortho voltage $(230 \mathrm{kV})$ to both testes and spermatic cords to the level of the internal iliac rings in 12 fractions over 16 days; one child (case 3), the only one in the series who had undergone orchidectomy, received only 1200 rads to the remaining testicle. Continuing chemotherapy with mercaptopurine, $\vec{\bullet}$ methotrexate, prednisolone, and vincristine as in the UKALL II protocol, ${ }^{6}$ or in two cases the UKALL V intermediate protocol, ${ }^{8}$ was given for two years.

The outcome in boys with isolated testicular relapse was compared with that in boys diagnosed during the same period as having a marrow relapse with or without concurrent testicular infiltration after electively stopping treatment. The management of these patients with induction, consolidation, regular intrathecal chemotherapy, and continuing treatment has been described in detail elsewhere. ${ }^{9}$ All patients were followed up until July 1982, a minimum period of 18 months after relapse.

\section{Results}

ISOLATED TESTICULAR RELAPSE AS A FIRST EVENT

Only two of the 169 boys with acute lymphoblastic leukaemia 8 developed early testicular relapse with overt infiltration during $₹$ chemotherapy $(1 \cdot 2 \%)$. One had $\mathrm{B}$ and one null acute lymphoblastic 윽 leukaemia with a high $\left(120 \times 10^{9} / \mathrm{l}\right)$ leucocyte count at presentation; both rapidly sustained a relapse in the marrow, despite further $\sigma$ induction and radiotherapy, and died.

Ninety-seven of the 169 boys $(57 \%)$ remained in first complete remission for two or three years and stopped treatment or, after 1977, N underwent testicular biopsy before a decision was made about N stopping treatment. Table I summarises the subsequent outcome in $\underset{\sigma}{\sigma}$

TABLE I-No of boys with acute lymphoblastic leukaemia undergoing testicular $\mathbb{\S}$ biopsy, and subsequent events

\begin{tabular}{|c|c|c|c|c|c|}
\hline \multirow{2}{*}{$\begin{array}{l}\text { Biopsy done } \\
\text { before treatment } \\
\text { stopped }\end{array}$} & \multirow{2}{*}{$\begin{array}{l}\text { No of } \\
\text { boys }\end{array}$} & \multirow{2}{*}{$\begin{array}{l}\text { No in } \\
\text { whom } \\
\text { biopsy } \\
\text { positive }\end{array}$} & \multicolumn{3}{|c|}{ Subsequent relapse } \\
\hline & & & Testis & $\begin{array}{l}\text { Testis }+ \\
\text { marrow }\end{array}$ & Marrow \\
\hline $\begin{array}{l}\text { No (as before 1977) } \\
\text { Yes }\end{array}$ & $\begin{array}{l}40\left(12^{*}\right) \\
57\end{array}$ & $\left(1^{*}\right)$ & $\begin{array}{l}5 \\
4\end{array}$ & $\begin{array}{l}5 \\
1\end{array}$ & $\begin{array}{r}7 \\
11\end{array}$ \\
\hline Totals & 97 & 5 & 9 & 6 . & 18 \\
\hline
\end{tabular}

*Late biopsy (see text) 
TABLE II-Clinical features in boys with isolated late testicular relapse

\begin{tabular}{|c|c|c|c|c|c|c|c|}
\hline $\begin{array}{l}\text { Case } \\
\text { No }\end{array}$ & $\begin{array}{l}\text { White cell } \\
\text { count at } \\
\text { presentation } \\
\left(\times 10^{\circ} / 1\right)\end{array}$ & $\begin{array}{c}\text { Type of acute } \\
\text { lymphoblastic } \\
\text { leukaemia } \\
\text { (ALL) }\end{array}$ & $\begin{array}{l}\text { Time after } \\
\text { treatment } \\
\text { stopped } \\
\text { (months) }\end{array}$ & $\begin{array}{c}\text { Clinical } \\
\text { infiltration } \\
\text { of testes }\end{array}$ & $\begin{array}{l}\text { Infiltration } \\
\text { on biopsy }\end{array}$ & Treatment & Result of follow-up \\
\hline $\begin{array}{l}1 \\
2 \\
3\end{array}$ & $\begin{array}{r}2 \cdot 3 \\
42 \cdot 0 \\
11.5\end{array}$ & $\begin{array}{l}\text { C-ALL } \\
\text { C-ALL }\end{array}$ & $\begin{array}{r}4 \\
4 \\
19\end{array}$ & $\begin{array}{l}\text { Both } \\
\text { Both } \\
\text { Left }\end{array}$ & $\begin{array}{l}\text { Bilateral } \\
\text { Bilateral } \\
\text { Bilateral }\end{array}$ & $\begin{array}{l}1500 \text { rads; induction only } \\
2400 \text { rads; induction only } \\
\text { Left orchidectomy; } \\
1200 \text { rads right testis; } \\
\text { chemotherapy }\end{array}$ & $\begin{array}{l}\text { Marrow relapse, } 8 \text { months } \\
\text { Marrow relapse, } 6 \text { months } \\
\text { Right testicular relapse at } 30 \text { months; } \\
\text { well in } 3 \text { rd remission }\end{array}$ \\
\hline $\begin{array}{c}4 \\
5 \\
6 \\
7 \\
8 \\
9^{*} \\
10^{*} \\
11 \\
12^{*} \\
13 \\
14^{*}\end{array}$ & $\begin{array}{r}14 \cdot 0 \\
6 \cdot 3 \\
7 \cdot 4 \\
5 \cdot 6 \\
29 \cdot 8 \\
10 \cdot 9 \\
10 \cdot 6 \\
53 \cdot 0 \\
100 \cdot 5 \\
42 \cdot 2 \\
1 \cdot 6\end{array}$ & $\begin{array}{l}\text { C-ALL } \\
\text { C-ALL } \\
\text { C-ALL } \\
\text { C-ALL } \\
\text { C-ALL } \\
\text { C-ALL } \\
\text { Null-ALL } \\
\text { T-ALL } \\
\text { C-ALL }\end{array}$ & $\begin{array}{r}4 \\
5 \\
15 \\
\\
9 \\
4 \\
3 \\
3\end{array}$ & $\begin{array}{l}\text { Both } \\
\text { Left } \\
\text { Left } \\
\text { Right } \\
\text { Left } \\
\text { Left }\end{array}$ & $\begin{array}{l}\text { Bilateral } \\
\text { Bilateral } \\
\text { Right } \\
\text { Bilateral } \\
\text { Bilateral } \\
\text { ? } \\
\text { Bilateral } \\
\text { Left } \\
\text { Bilateral } \\
\text { Right } \\
\text { Left }\end{array}$ & $\begin{array}{l}\text { Standard } \\
\text { Standard } \\
\text { Standard } \\
\text { Standard } \\
\text { Standard } \\
\text { Standard } \\
\text { Standard } \\
\text { Standard } \\
\text { Standard } \\
\text { Standard } \\
\text { Standard }\end{array}$ & $\begin{array}{l}\text { Well, } 65+\text { months } \\
\text { Well, } 55+\text { months } \\
\text { Well, } 53+\text { months } \\
\text { Well, } 45+\text { months } \\
\text { Well, } 45+\text { months } \\
\text { Well, } 44+\text { months } \\
\text { Well, 44 + months } \\
\text { Well, } 45+\text { months } \\
\text { Well, } 34+\text { months } \\
\text { Well, } 29+\text { months } \\
\text { Marrow relapse, } 6 \text { months }\end{array}$ \\
\hline
\end{tabular}

*Patients in whom previous biopsy had yielded negative results.

these 97 boys. Isolated testicular relapse occurred in 14; table II shows details of these patients. Five boys developed overt testicular leukaemia before the introduction of routine biopsies. In four boys (cases 7, 8, 11,13 ) infiltration was found at biopsy at the time stopping treatment was planned, and in one boy (case 6) infiltration was found at recall. In four boys (cases $9,10,12,14)$ a previous biopsy had yielded a negative result; one of these boys (case 14) had subsequently had 12 months of further treatment, and relapse occurred three months after treatment was stopped.

Four of the boys with unilateral swelling had bilateral infiltration on biopsy, one had unilateral infiltration, and in the sixth (case 9) a biopsy specimen was not taken from the other testis.

\section{BONE-MARROW RELAPSE}

Twenty-four boys had a relapse in the marrow after stopping treatment, of whom six had concurrent testicular infiltration. Five of these boys had not undergone testicular biopsy before treatment was stopped, and in one a biopsy five months previously had yielded a negative result. Eleven of the 18 boys who sustained a relapse in the marrow without clinical testicular infiltration had undergone testicular biopsy before stopping treatment, with negative results.

\section{OUTCOME AFTER ISOLATED TESTICULAR RELAPSE}

The figure shows the outcome in the 14 boys with testicular disease found at biopsy or who had an isolated testicular relapse after stopping treatment compared with that in the 24 boys who during the same period had a relapse in the marrow after stopping treatment, with or without testicular infiltration.

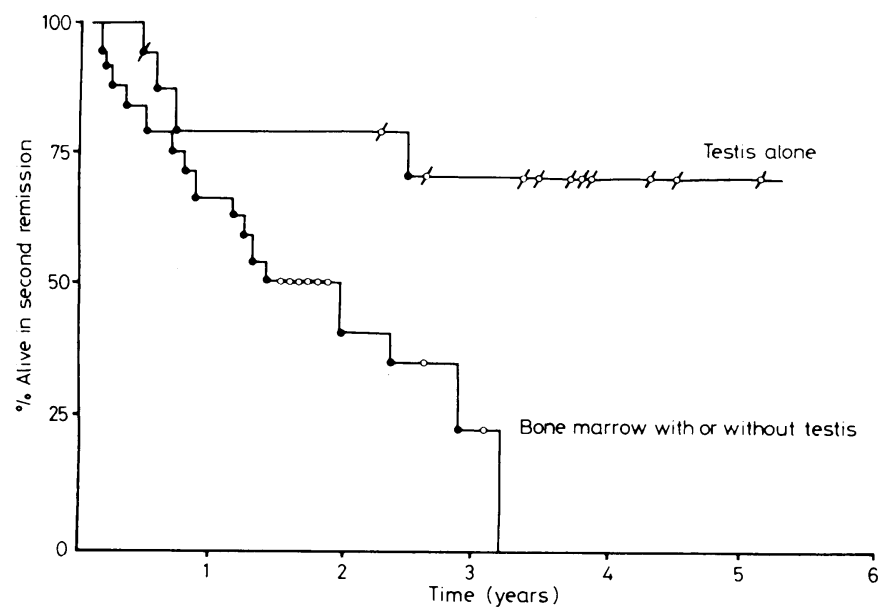

Comparison of duration of second complete remission in boys with late isolated testicular relapse and boys with bone-marrow relapse after treatment stopped. $\delta, \delta$ Denotes boys given standard treatment described in text.
Ten of the 11 boys with isolated testicular relapse who received the standard protocol remained in second remission after completing two years' treatment. The two boys who received only local treatment (cases 1 and 2) soon had a relapse in the bone marrow. One boy (case 3 ), treated with only 1200 rads to his remaining testicle, developed recurrent testicular infiltration six months after stopping treatment a second time. He was treated with further irradiation and chemotherapy and remained in third remission 28 months after his second testicular relapse. By contrast, the outcome in boys with marrow relapse with or without testicular infiltration was less satisfactory, one-half having had a second relapse by 18 months.

\section{Discussion}

The boys in whom biopsy showed testicular disease or who developed late overt infiltration of the testicles who received standard treatment with chemotherapy and local irradiation ( 2400 rads) fared considerably better than boys who developed a marrow relapse after stopping treatment or boys who developed overt testicular relapse during treatment. It is hardly surprising in retrospect that the two boys with apparently localised disease who received only local treatment subsequently developed a marrow relapse. Extensive investigations in a small group of boys with apparent local testicular infiltration showed that, in some at least, the disease affected paraortic lymph nodes. ${ }^{10}$

Our results of treatment of isolated testicular relapse compare favourably with those in other small series of patients ${ }^{11-13} ; 10$ of the 11 boys who received standard treatment remained well. The recurrence of testicular disease in the patient in case 3 confirms previous reports that a dose of radiotherapy in the order of 2400 rads is necessary for local control of testicular disease. ${ }^{14}{ }^{15}$ This dose will certainly cause azoospermia, ${ }^{16}$ but its precise effect on the function of Leydig's cells remains uncertain. Bilateral irradiation appears to be indicated in view of the high incidence of bilateral disease and of false-negative biopsy results.

The results of this study call into question the value of routine testicular biopsy at two years in early diagnosis of infiltration. In five of the patients with overt infiltration a previous biopsy had yielded negative results; in one this had preceded a third year of chemotherapy and overt infiltration had followed 15 months later. Since a positive biopsy result makes immediate treatment of early infiltration possible and avoids, in some children at least, the trauma of restarting treatment, we continue at present to advocate the use of routine biopsy before treatment is stopped. The use of more sophisticated techniques such as immunofluorescence examination of specimens for cells containing terminal deoxynucleotidyl transferase may permit more accurate diagnosis of infiltration. ${ }^{17}$ Routine testicular biopsy did not reduce the incidence of marrow relapse after treatment was stopped. Twelve of the 24 boys with marrow relapse had previously undergone testicular biopsy with negative results. It is not clear whether this failure to prevent late marrow relapse 
by early diagnosis of testicular disease is evidence against "reseeding" of the marrow from the testis or merely evidence of failure to detect minimal disease in the testicle.

The reasons for the high incidence of testicular relapse in some centres are not clear; in general it appears that schedules associated with a high risk of testicular infiltration are also those associated with a high risk of relapse in boys after treatment is stopped and those in which boys tend overall to do worse than girls. ${ }^{12}$ If, as seems probable, testicular relapse is a sign of widespread residual disease, more intensive systemic chemotherapy may eliminate this difference in outcome between the sexes and reduce the incidence of testicular leukaemia.

We thank Mr Herbert Eckstein, consultant surgeon, Hospital for Sick Children, and Dr John Pincott, department of histopathology, for their help. KT was supported by the Leukaemia Research Fund and was in receipt of an Uncle Bob's and Jeannie Poolman travelling scholarship.

\section{References}

${ }^{1}$ Medical Research Council Working Party on Leukaemia in Childhood. Effects of varying radiation schedule, cyclophosphamide treatment and duration of treatment in acute lymphoblastic leukaemia. $\mathrm{Br}$ Med $\mathrm{f}$ 1978;ii:787-91.

2 Sather H, Miller D, Nesbit M, Heyn N, Hammond D. Differences in prognosis for boys and girls with acute lymphoblastic leukaemia. Lancet $1981 ; \mathrm{i}: 739-44$.

${ }^{3}$ Medical Research Council Working Party on Leukaemia in Childhood. Testicular disease in acute lymphoblastic leukaemia in childhood. $\mathrm{Br}$ Med 7 1978; :334-8.

${ }^{4}$ Land VJ, Berry DH, Herson J, et al. Long-term survival in childhood acute leukaemia: "late" relapses. Med Pediatr Oncol 1979;7:19-24.

5 Nesbit ME, Robison LL, Ortega JA, Sather HN, Donaldson M, Hammond
D. Testicular relapse in childhood acute lymphoblastic leukaemia: association with pretreatment patient characteristics and treatment. Cancer 1980;45:2009-16.

${ }^{6}$ Medical Research Council Working Party on Leukaemia in Childhood. Analysis of treatment in childhood leukaemia. II. Timing and the toxicity of combined 6-mercaptopurine and methotrexate maintenance therapy. Br $\mathcal{F}$ Haematol $1976 ; 33: 179-88$.

7 Medical Research Council Working Party on Leukaemia in Childhood Analysis of treatment in childhood leukaemia. V. Advantage of reducing chemotherapy during and immediately after cranial irradiation. $\mathrm{Br} \mathcal{J}$ Cancer 1977;36:625-33.

${ }^{8}$ Rapson NT, Cornbleet MA, Chessells JM, Bennett T, Hardisty RM. Immunosuppression and serious infections in children with acute lymphoblastic leukaemia. A comparison of three chemotherapy regimes. Br $\mathcal{F}$ Haematol $1980 ; 45 ; 41-52$.

9 Chessells JM, Breatnach F. Late marrow recurrences in childhood acute lymphoblastic leukaemia. Br Med F $1981 ; 283: 749-51$.

${ }^{10}$ Baum E, Nesbit M Jr, Tilford D, Heyn R, Krivit W. Extent of disease in pediatric patients with acute lymphocytic leukaemia experiencing an apparent isolated testicular relapse. [Abstract.] Proceedings of the American Society of Clinical Oncology 1979;20:435.

11 Hustu HO, Aur RJA. Extramedullary leukaemia. Clin Haematol 1978; 313-37.

12 Oakhill H, Mainwaring D, Hill FGH, et al. Management of leukaemic infiltration of the testis. Arch Dis Child 1980;55:564-6.

13 Wong KY, Ballard ET, Strayer FH, Kisker T, Lampkin B. Clinical and occult testicular leukemia in long-term survivors of acute lymphoblastic leukemia. $\mathcal{F}$ Pediatr 1980;96:567-74.

14 Sullivan MP, Perez CA, Herson J, et al. Radiotherapy $(2500 \mathrm{rad})$ for testicular leukaemia. Local control and subsequent clinical events: a south-west oncology group study. Cancer 1980;46:508-15.

15 Atkinson K, Thomas PRM, Peckham MJ, McElwain TJ. Radiosensitivity of the acute leukaemic infiltrate. Eur $\mathcal{F}$ Cancer 1976;12:535-40.

16 Ash P. The influence of radiation on fertility in man. Br $\mathcal{F ~ R a d i o l ~ 1 9 8 0 ; ~}$ $53: 271$.

17 Thomas JA, Janossy G, Eden OB, Bollum FJ. Nuclear terminal deoxynucleotidyl transferase in leukaemic infiltrates of testicular tissue. $\mathrm{Br} \mathcal{F}$ Cancer 1982;45:709-17.

(Accepted 29 September 1982) .

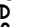

